\title{
Modelování produkce stavebních společností Metrostav a.s. a Skanska a.s.
}

\author{
Josef Tuma \\ Vedoucí práce: RNDr. Jitka Bartošová, Ph.D.
}

\begin{abstract}
Úvod
Hlavním důvodem, proč jsem se začal zabývat problematikou týkající se produkční funkce, byla skutečnost, že jsem na internetu četl článek (viz příloha č. 1) týkající se stavební společnosti Metrostav a.s., kde se zmiňovali o hospodářských výsledcích a rostoucí výkonnosti. Toto téma mne natolik zaujalo, že jsem se rozhodl, hledat další data, pracovat s nimi a modelovat je. Očekával jsem, že bych mohl dojít k dalším zajímavým poznatkům. Rovněž jsem vyhledal data, týkající se společnosti Skanska a.s.. Tuto společnost jsem zvolil, protože již z vlastních zkušeností vím, že se jedná o společnost procující ve stejném oboru a také se domnívám, že je nejvhodnější (ze stavebních společností) pro srovnávaní se spol. Metrostav a.s..

Data spol. Metrostav a.s. jsem získal z výročních zpráv z let 1996-2005. Jedná se universální stavební společnost zajiš ující řízení a realizaci náročných stavebních děl. Metrostav a.s. se řadí mezi nadprůměrně prosperující středoevropské stavební firmy s trvalým růstem své produkce, tržní hodnoty a s úrovní ruízení odpovídající standardům EU. Data spol. Skanska a.s. jsem získal z výročních zpráv z let 2001-2005. Mezi hlavní činnosti této společnosti paří pozemní, dopravní a inženýrské stavitelství.
\end{abstract}

\section{Tvorba modelu a práce s modelem}

V praktické části bych chtěl pomocí tabulek a grafů znázornit získaná data, která ovlivňují produkční funkci, a poté namodelovat produkční funkce obou zmiňovaných společností. Pomocí grafư a tabulek bude možno pozorovat dosavadní vývoj zmiňovaných ukazatelů ve společnostech. V následujících krocích budu rozebírat data společnosti Metrostav a.s. získané z výročních zpráv 1996-2005. V tabulce č. 1 jsou údaje hlavních hospodářských ukazatelů (kapitál, tržby a celková aktiva). Údaje jsou uvedeny v tisících Kč. 
Tab. č. 1: Hospodářské ukazatele spol. Metrostav a.s.

\begin{tabular}{||c|c|c|c|}
\hline ROK & KAPITÁL & TRŽBY & AKTIVA CELKEM \\
\hline 1996 & 782568 & 4922082 & 3035130 \\
\hline 1997 & 1085864 & 5849325 & 3156977 \\
\hline 1998 & 1191815 & 5406106 & 3157677 \\
\hline 1999 & 1240980 & 6906758 & 3573239 \\
\hline 2000 & 1339077 & 7917348 & 4043263 \\
\hline 2001 & 1352772 & 9464295 & 5717763 \\
\hline 2002 & 1688971 & 12157033 & 6616831 \\
\hline 2003 & 2016809 & 13662827 & 8021316 \\
\hline 2004 & 2346223 & 18106286 & 10061501 \\
\hline 2005 & 2833587 & 20786110 & 11346916 \\
\hline
\end{tabular}

V tabulce č. 1 lze pozorovat nárůst hodnot u všech ukazatelů. Z těchto dat jsem vytvořil graf (graf č. 1), na kterém lze lépe zachytit vývoj kapitálu, tržeb a celkových aktiv v horizontu 10 let, rychlost jejich růstu, množství a vzájemný poměr.

Z grafu č. 1 lze vyčíst, že množství kapitálu vcelku rovnoměrně rostlo, zatímco tempo růstu celkových aktiv a tržeb se od určitého období zrychlilo. Tuto změnu tempa růstu můžeme nejlépe pozorovat u tržeb na přelomu let 1998 a 1999.

\section{Graf č. 1: Vývoj vlastního kapitálu, tržeb a celkových aktiv}

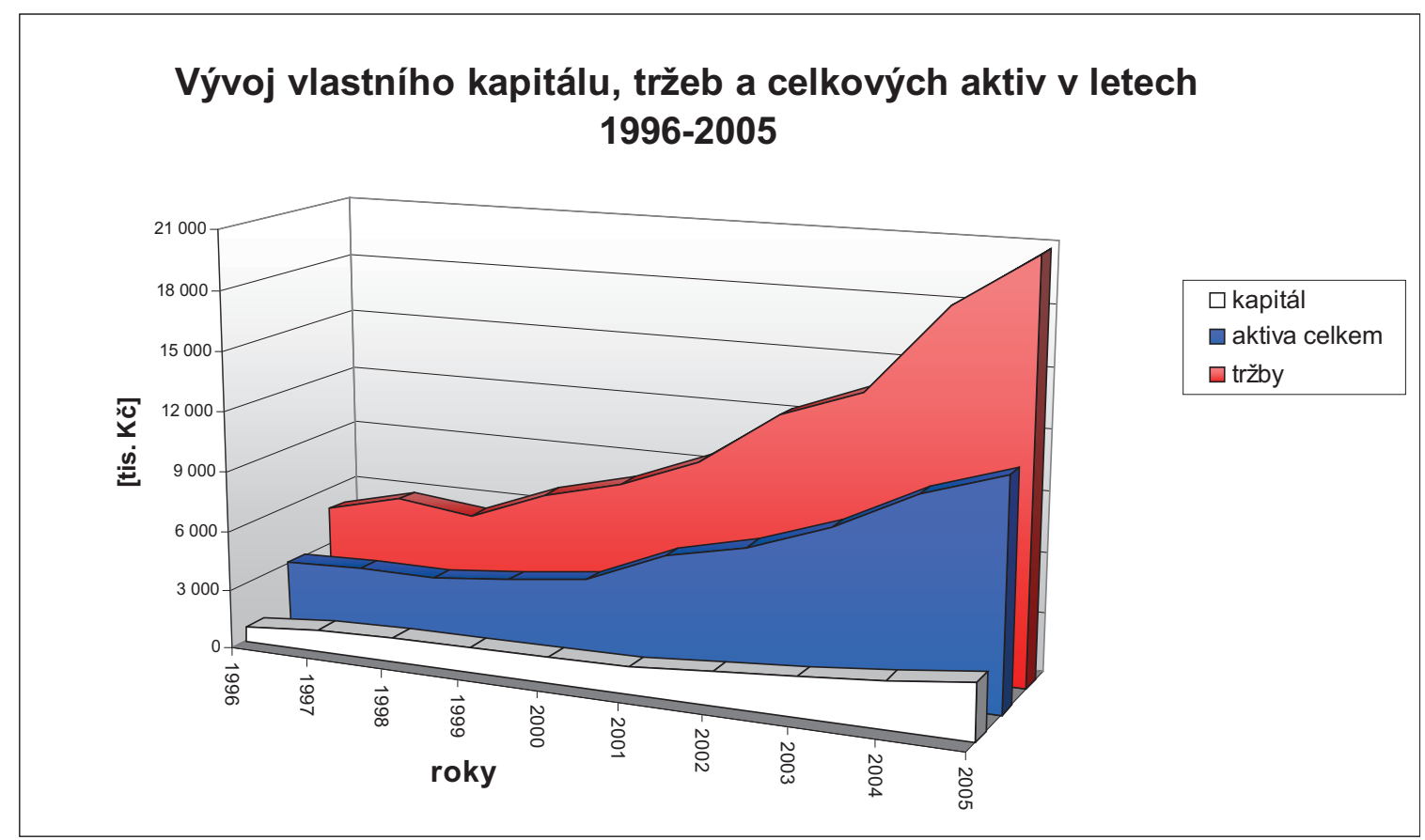

Jelikož při tvorbě Cobb-Douglasovy produkční funkce pracujeme se vstupy práce L, což je v našem př́padě počet odpracovaných hodin, který závisí na množství pracovníků, uvádím v následující tabulce č. 2 množství počtu zaměstnanců v letech 1996-2005. 
Tab. č. 2: Průměrný přepočtený stav zaměstnanců

\begin{tabular}{|c|c|c|c|c|c|c|c|c|c|c|}
\hline ROK & $\mathbf{1 9 9 6}$ & $\mathbf{1 9 9 7}$ & $\mathbf{1 9 9 8}$ & $\mathbf{1 9 9 9}$ & $\mathbf{2 0 0 0}$ & $\mathbf{2 0 0 1}$ & $\mathbf{2 0 0 2}$ & $\mathbf{2 0 0 3}$ & $\mathbf{2 0 0 4}$ & $\mathbf{2 0 0 5}$ \\
\hline $\begin{array}{l}\text { průměrný přepočtený } \\
\text { stav zaměstnanců }\end{array}$ & 3338 & 3349 & 3237 & 2998 & 2902 & 2923 & 3130 & 3133 & 3139 & 3329 \\
\hline
\end{tabular}

Opět pro lepší představu jsem zanesl data týkající se průměrného počtu zaměstnanců do grafu č. 2, který umožňuje pomocí grafického znázornění vytvořit lepší představu o dosavadním vývoji. Je z něj patrné, že počet zaměstnanců není konstantní a že se nerovnoměrně zvyšuje či snižuje.

\section{Graf č. 2: Vývoj počtu zaměstnanců}

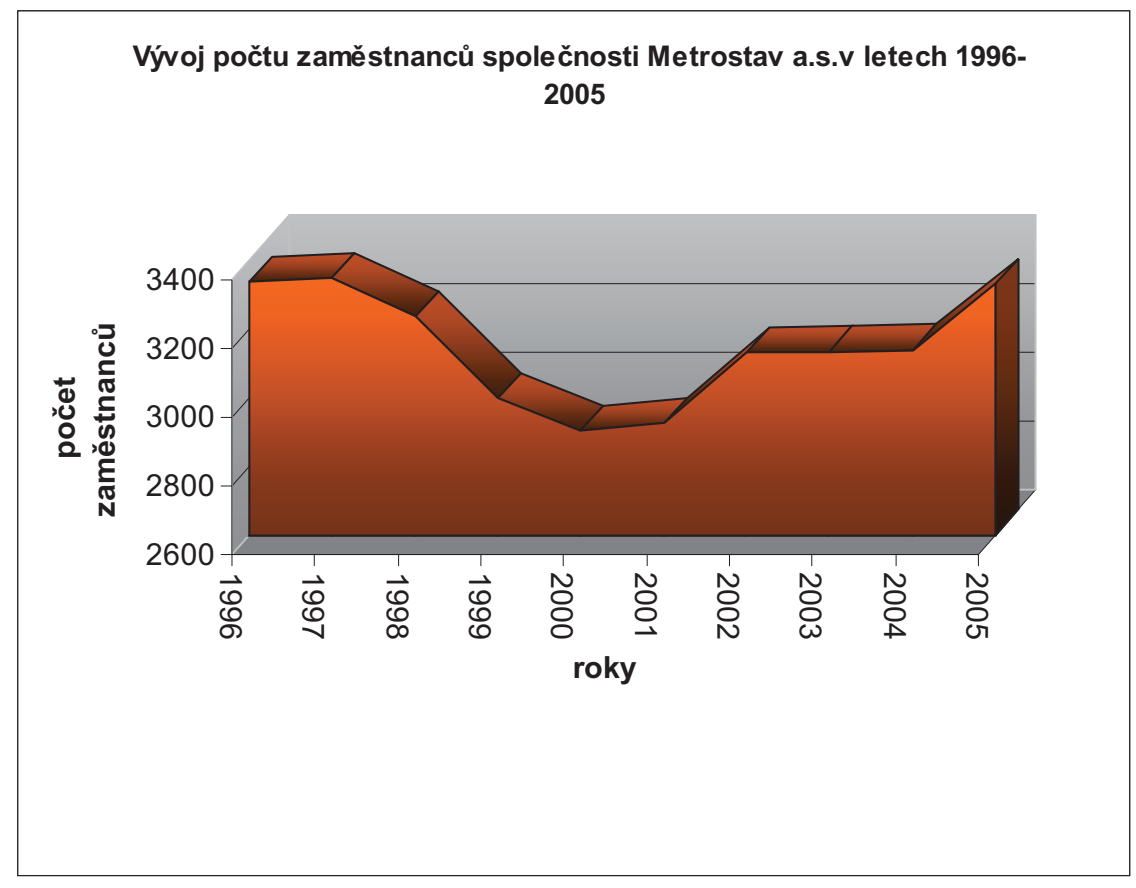

V tabulce č. 3 uvádí údaje týkající se velikosti zisku, který měla firma na jednoho zaměstnance za období jednoho měsíce.

Tab. č. 3: Průměrný zisk společnosti na jednoho zaměstnance

\begin{tabular}{||c|c|c|c|c|c|c|c|c|c|c|}
\hline \multicolumn{1}{|c|}{ ROK } & $\mathbf{1 9 9 6}$ & $\mathbf{1 9 9 7}$ & $\mathbf{1 9 9 8}$ & $\mathbf{1 9 9 9}$ & $\mathbf{2 0 0 0}$ & $\mathbf{2 0 0 1}$ & $\mathbf{2 0 0 2}$ & $\mathbf{2 0 0 3}$ & $\mathbf{2 0 0 4}$ & $\mathbf{2 0 0 5}$ \\
\hline \hline $\begin{array}{l}\text { zisk na zaměstnance } \\
\text { v [tis. Kč] }\end{array}$ & 28 & 41 & 48 & 40 & 52 & 69 & 93 & 122 & 145 & 211 \\
\hline
\end{tabular}

Opět jsem údaje z tabulky č. 3 znázornil graficky na grafu č. 3., na kterém lze pozorovat nárůst tempa růstu od roku 1999. S čímž souvisí nárůst tržeb, který jsme mohli pozorovat již dř́ve na grafu č. 1 a v tabulce č. 1 . 
Graf č. 3: Průměrný zisk společnosti na jednoho zaměstnance

\section{Průměrný zisk společnosti Metrostav a.s. $v$ [tis. Kč] na zaměstnance $v$ letech 1996-2005}

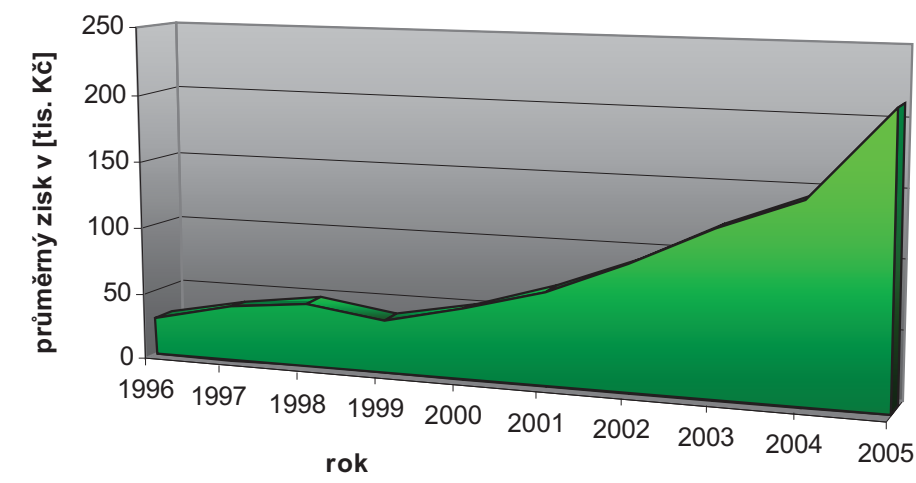

S vývojem zisků na jednoho zaměstnance úzce souvisí vývoj průměrného měsíčního nominálního výdělku zaměstnance. Ten lze vypozorovat $\mathrm{z}$ dat jež jsou uvedena $\mathrm{v}$ tabulce č. 4 a graficky znázorněna $v$ grafu č. 4 . Z nichž lze poté vyčíst, že se průměrný měsíční výdělek neustále zvyšuje. Od roku 2001 pozorujeme také zrychlení tempa růstu.

Tabulka č. 4: Měsíční nominální výdělek

\begin{tabular}{|c|c|c|c|c|c|c|c|c|c|c|}
\hline ROK & $\mathbf{1 9 9 6}$ & $\mathbf{1 9 9 7}$ & $\mathbf{1 9 9 8}$ & $\mathbf{1 9 9 9}$ & $\mathbf{2 0 0 0}$ & $\mathbf{2 0 0 1}$ & $\mathbf{2 0 0 2}$ & $\mathbf{2 0 0 3}$ & $\mathbf{2 0 0 4}$ & $\mathbf{2 0 0 5}$ \\
\hline \hline $\begin{array}{l}\text { měsíční nominální } \\
\text { výdělek v [Kč] }\end{array}$ & 13152 & 14953 & 16294 & 17831 & 19134 & 20552 & 23724 & 26041 & 29455 & 32828 \\
\hline \hline
\end{tabular}

\section{Graf č. 4: Vývoj měsíčních nominálních výdělků}

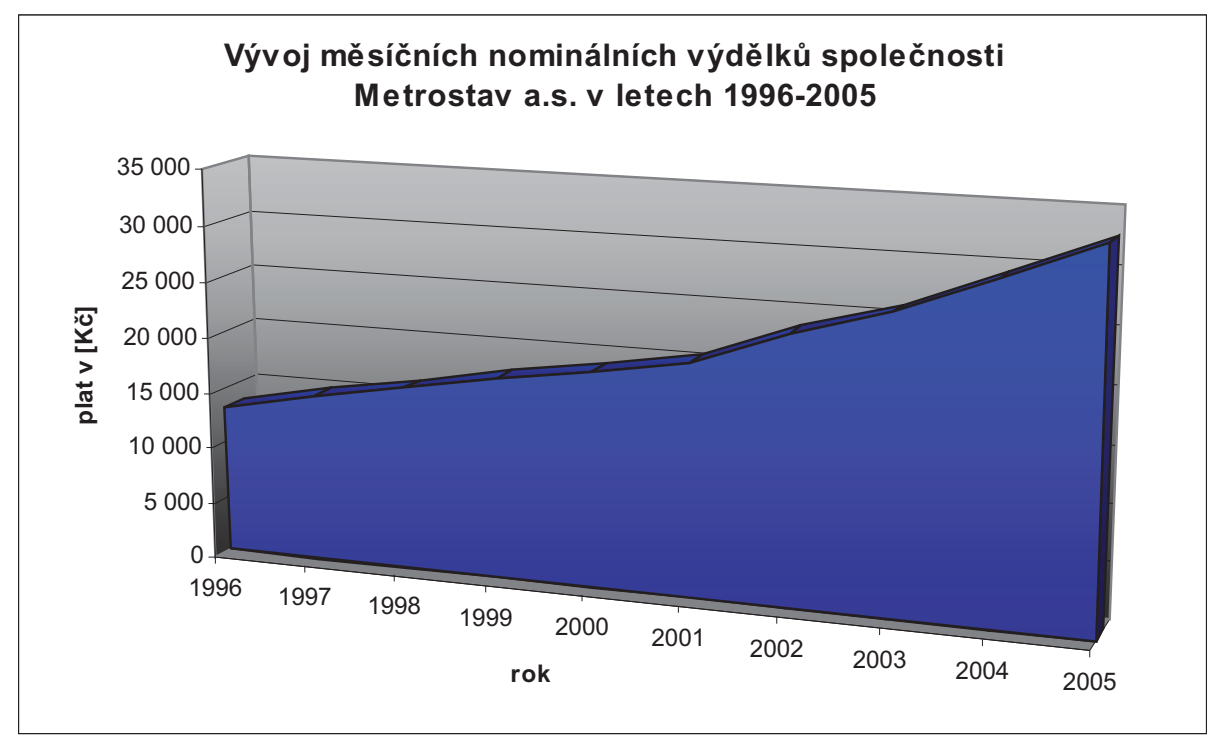

A jelikož už víme jak probíhal vývoj zisků na jednoho zaměstnance a jeho průměrného měsíčního nominálního výdělku, lze si udělat jasnou představu o „spravedlivosti“ ohodnocování pracovníků (viz graf č. 5). Na tomto grafu jasně vidíme, že výdělky zaměstnanců rostly (vcelku rovnoměrně), ale neúměrně k měsíčním ziskům, který měla společnost ze za- 
městnance. Kdyby měly být nominální výdělky vzhledem $\mathrm{k}$ měsíčním ziskům „,spravedlivé“, pak by křivka grafu znázorňujícího výdělek měla mít stejný prủběh (tvar) jako křivka grafu jenž znázorňuje měsíční zisk.

\section{Graf č. 5: Porovnání prům. nominálních zisků spol. na zaměstnance a výdělků zaměstnanců}

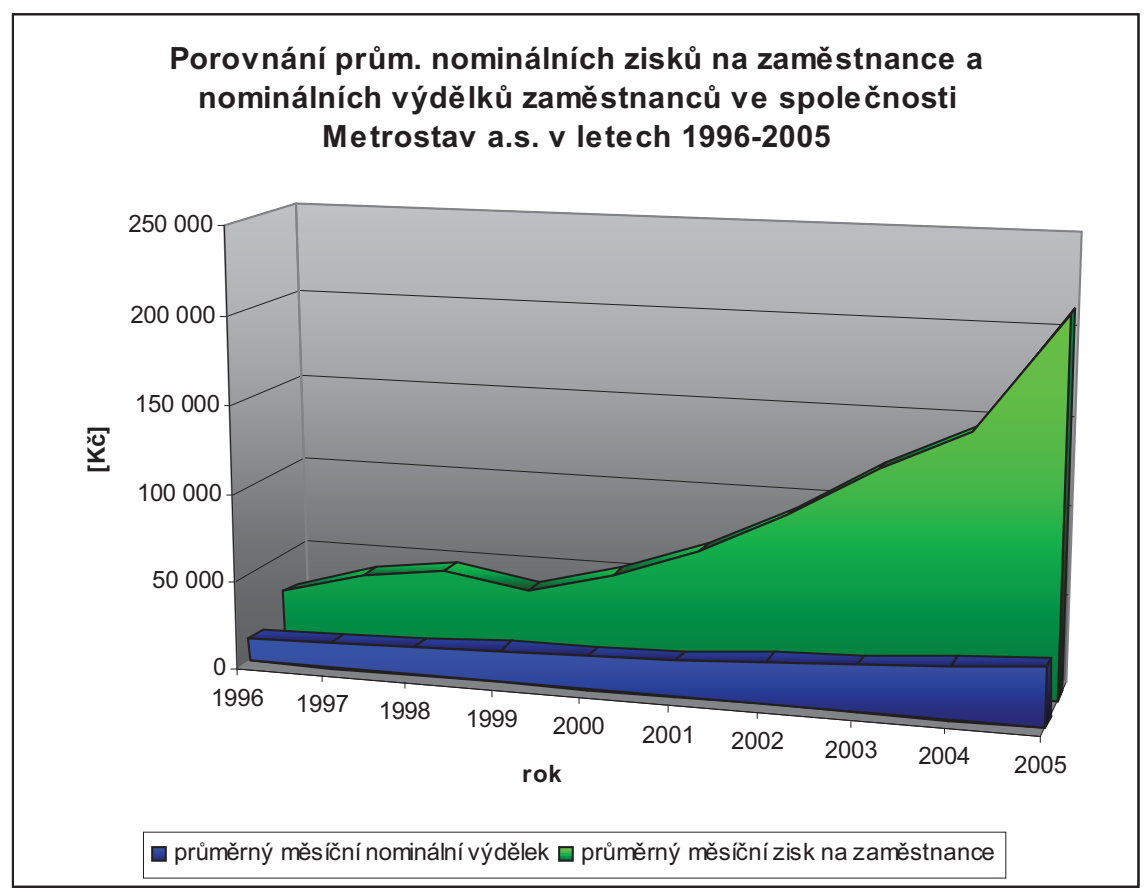

V následujících krocích budu rozebírat data týkající se společnosti Skanska a.s. získané z výročních zpráv 2001-2005.

V tabulce č. 5 jsou údaje o kapitálu, tržbách a celkových aktivech. Údaje jsou uvedeny v tis. a následně zobrazena graficky (viz graf č. 6).

Tab. č. 5: Hodnoty kapitálu, tržeb a celkových aktiv spol. Skanska a.s.

\begin{tabular}{|c|c|c|c||}
\hline ROK & KAPITÁL & TRŽBY & AKTIVA CELKEM \\
\hline \hline 2001 & 3709000 & 23938000 & 12232000 \\
\hline 2002 & 4592000 & 28511000 & 17524000 \\
\hline 2003 & 5702000 & 29462000 & 21581000 \\
\hline 2004 & 6978000 & 33903000 & 23101000 \\
\hline 2005 & 6776000 & 36455000 & 24036000 \\
\hline
\end{tabular}

Na následujících grafech č. 7 a č. 8 jsou zobrazeny údaje obou společností týkající se tržeb kapitálu a celkových aktiv v období 2001-2005 (délka tohoto období je dána nemožností získat starší data společnosti Skanska a.s.). Údaje týkající se společnosti Metrostav a.s. jsou uváděny s označením $\mathrm{M}$ a údaje týkající se společnosti Skanska a.s. s označením S. Ovšem nelze společně srovnávat získané hodnoty, jelikož společnost Skanska a.s.ve svých výročních zprávách uvádí data, která jsou společná pro ČR a SR. My zde ale můžeme pozorovat a srovnávat tempo růstu či poklesu. U společnosti Skanska a.s. pozorujeme rychlejší tempo růstu kapitálu a $\mathrm{v}$ minulých letech velmi rychlé tempo růstu celkových aktiv, které se již zpomalilo a je srovnatelné s tempem růstu celkových aktiv 
u společnosti Metrostav a.s.. Co se týče tempa růstu tržeb, je takřka stejné u obou společností.

Graf č. 6: Vývoj vlastního kapitálu , tržeb a celkových aktiv

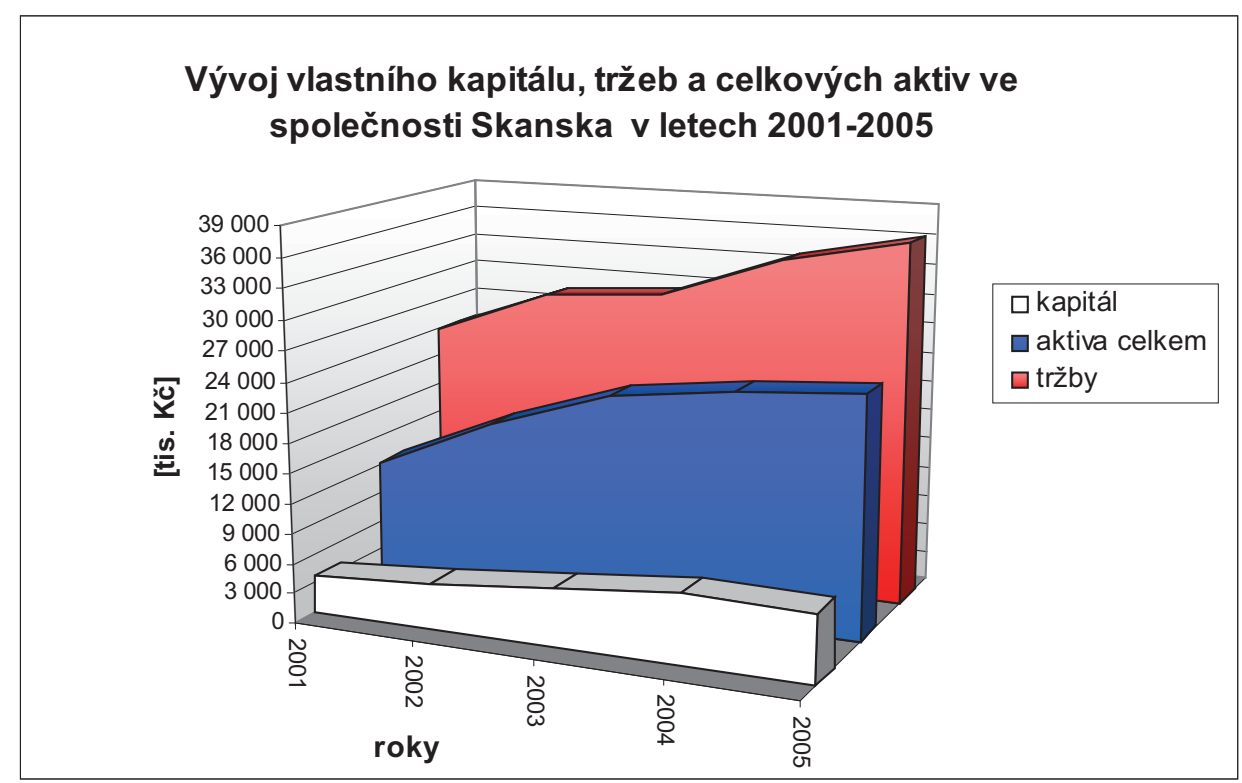

Graf č. 7: Vývoj vlastního kapitálu a celkových aktiv ve společnostech

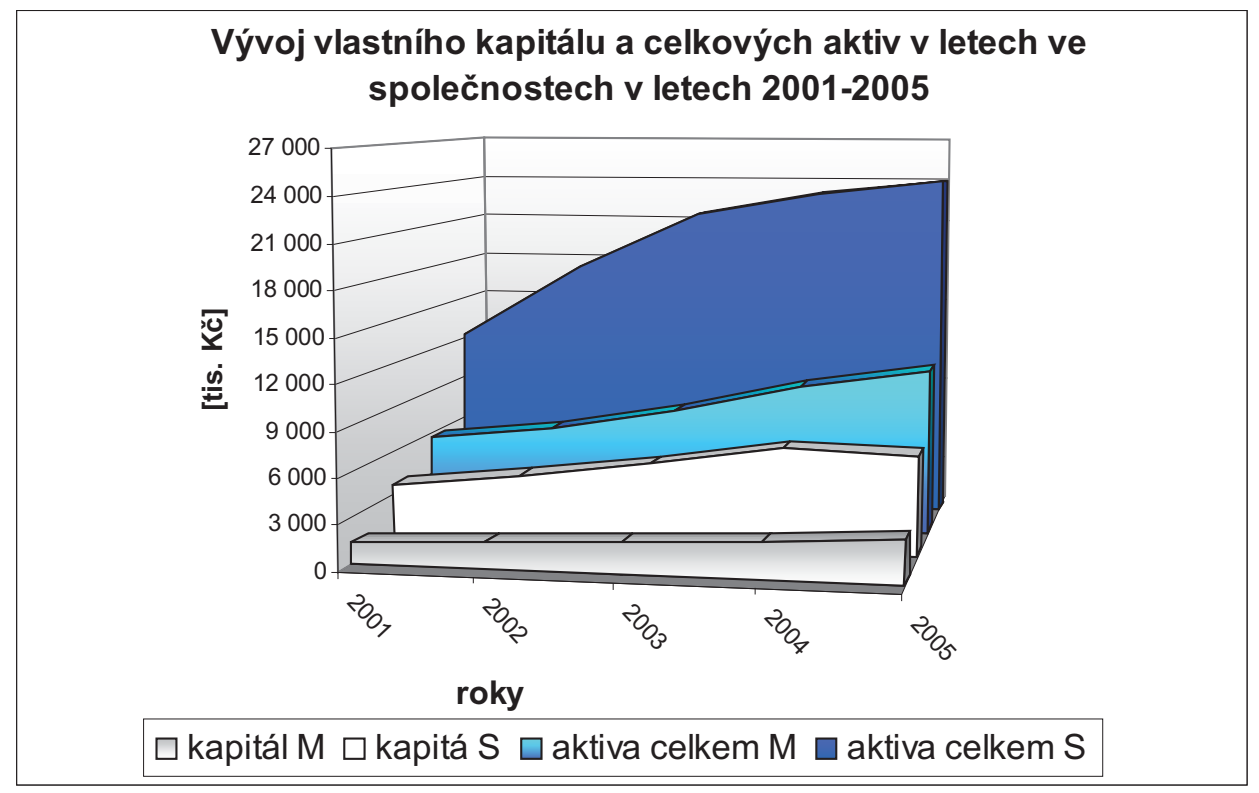




\section{Graf č. 8: Vývoj tržeb ve společnostech}

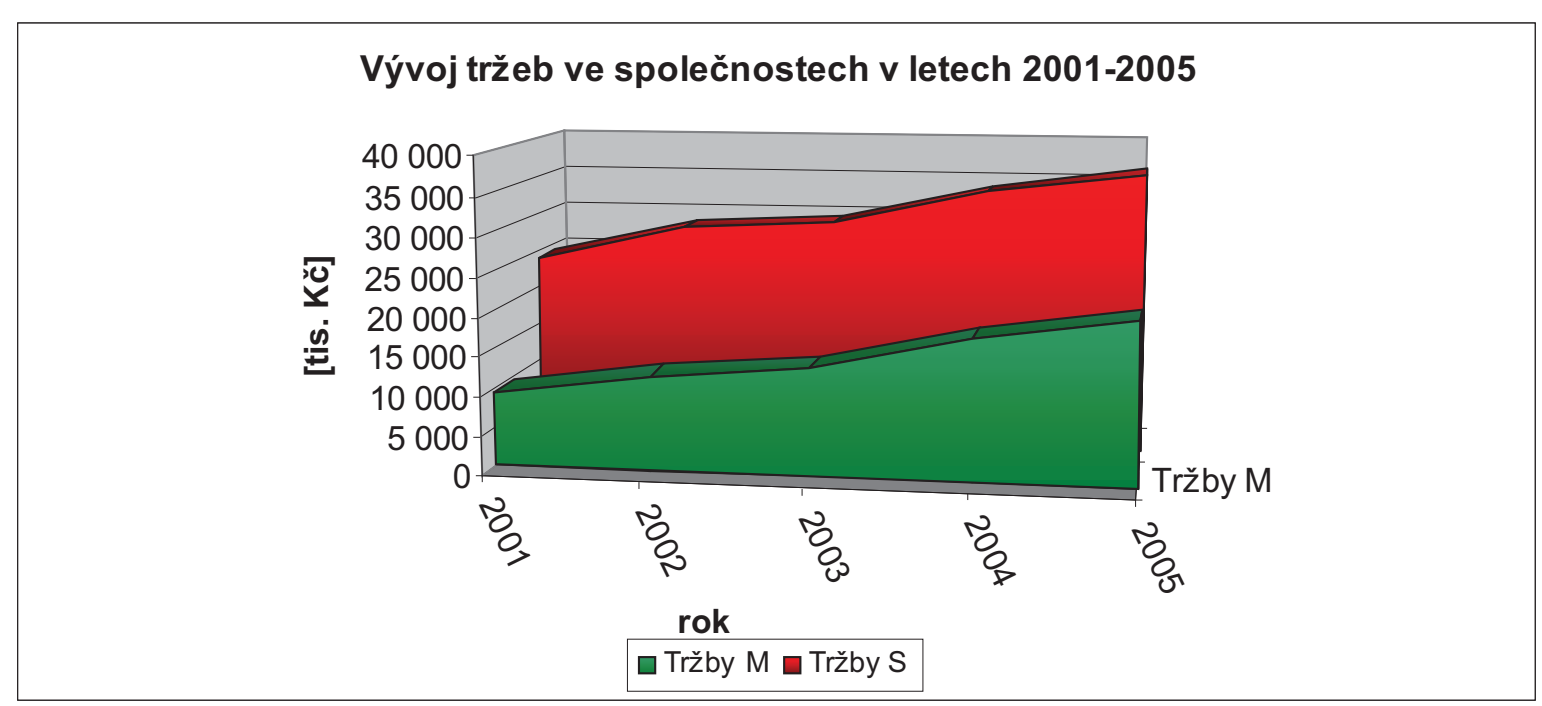

\section{Modelování produkčních funkcí} tvar

Zjednodušený tvar produkční funkce, ze které budeme při modelování vycházet má

$$
Q=f(K, L)
$$

kde Q množství výstupu (v našem případě velikost tržeb v tis. Kč),

K množství vstupů kapitálu (vlastní kapitál v tis. Kč.),

L množství vstupů práce, jelikož ve výročních zprávách se udává průměrný přepočtený stav zaměstnanců, je nutné jejich počet převést na množství odpracovaných hodin.

Počet zaměstnanců lze převést na počet odpracovaných hodin (vstup L) následovně. V zákoníku práce pro rok 2007 se uvádí, že zaměstnanec musí za rok odpracovat 2008 hodin. Tudíž počet odpracovaných hodin v tisících vypočítáme:

$$
L=" \text { počet zaměstnancü" } \cdot 2008 / 1000 .
$$

Z existujících modelů produkční funkce jsem si vybral model statické Cobb-Douglasuvy produkční funkce, která se mi jeví jako nejvhodnější. Její tvar je

$$
Q=f(K, L)=a_{0} K^{a_{1}} L^{a_{2}} .
$$




\section{Postup odhadu parametrů Cobb-Douglasovy produkční funkce pomocí programu MS Excel}

1) v hlavní lište vybereme panel nástroje modul Analýza dat

\begin{tabular}{|c|c|c|c|}
\hline ožit Eormát & Nástroje & Data $\underline{\text { Oknı }}$ & \\
\hline 希 酥 & ABg Pra & ppis... & $\mathrm{F} 7$ \\
\hline & $\underline{Z} \mathrm{drc}$ & e informací... & Alt+klepnutí \\
\hline A & (4) Kon & cola chyb... & \\
\hline & Dop & iky... & \\
\hline & Wlas & & \\
\hline & Mož & osti... & \\
\hline & Ana & zza dat... & \\
\hline & & $\approx$ & \\
\hline
\end{tabular}

2) v nabídce vybereme nástroj Regrese

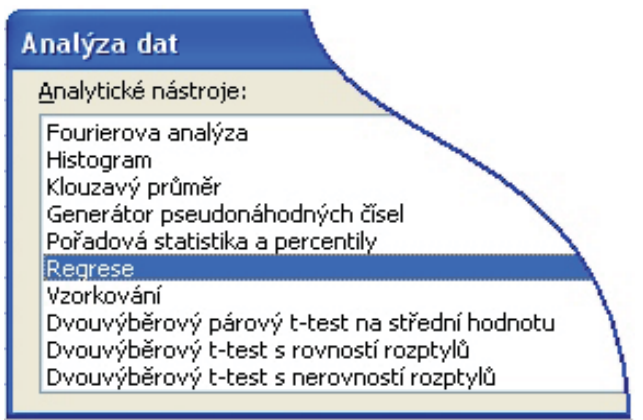

3) do políček vložíme odkaz na

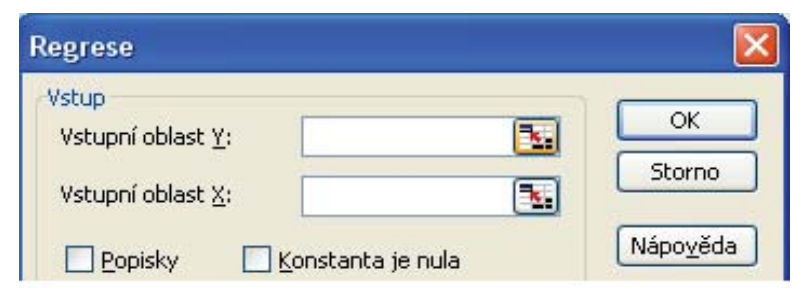

Do políčka vstupní oblast Y vložíme oblast se zlogaritmovanými hodnotami výstupu Q, do políčka X vložíme oblast se zlogaritmovanými hodnotami vstupů K a L. Poté dostaneme hodnoty koeficientů $a_{1}, a_{2}$, které jsou označeny jako Soubor X1, X2 (hodnoty koeficientů jsou zde nyní uvedeny pouze jako názorná ukázka).

\begin{tabular}{l|r}
\hline & \multicolumn{1}{c}{ Koeficienty } \\
\hline Hranice & 0,294753689 \\
\hline Soubor X1 & 1,275149815 \\
\hline Soubor X2 & $-0,270260171$ \\
\hline
\end{tabular}

Koeficient získáme exponováním hodnoty „Hranice“. Dále zbývá pouze dosadit do rovnice.

\section{Produkční funkce Metrostav a.s.}

Nyní budu zjiš ovat tvar produkční funkce spol.Metrostav a.s. Máme hodnoty $K, Q$ a je nutno získat hodnoty $L$. Ty získáme podle již dřív zmiňovaného vzorce:

$$
L=" \text { počet zaměstnancü" } \cdot 2008 / 1000
$$




\begin{tabular}{||c|c|c|c||}
\hline ROK & K & Q & počet zaměstnanců \\
\hline \hline 1996 & 782568 & 4922082 & 3338 \\
\hline 1997 & 1085864 & 5849325 & 3349 \\
\hline 1998 & 1191815 & 5406106 & 3237 \\
\hline 1999 & 1240980 & 6906758 & 2998 \\
\hline 2000 & 1339077 & 7917348 & 2902 \\
\hline 2001 & 1352772 & 9464295 & 2923 \\
\hline 2002 & 1688971 & 12157033 & 3130 \\
\hline 2003 & 2016809 & 13662827 & 3133 \\
\hline 2004 & 2346223 & 18106286 & 3139 \\
\hline 2005 & 2833587 & 20786110 & 3329 \\
\hline
\end{tabular}

\begin{tabular}{|c|c|c|}
\hline ROK & počet zaměstnanců & L \\
\hline 1996 & 3338 & 6702,704 \\
\hline 1997 & 3349 & 6724,792 \\
\hline 1998 & 3237 & 6499,896 \\
\hline 1999 & 2998 & 6019,984 \\
\hline 2000 & 2902 & 5827,216 \\
\hline 2001 & 2923 & 5869,384 \\
\hline 2002 & 3130 & 6285,04 \\
\hline 2003 & 3133 & 6291,064 \\
\hline 2004 & 3139 & 6303,112 \\
\hline 2005 & 3329 & 6684,632 \\
\hline
\end{tabular}

\begin{tabular}{|c|c|c|c||}
\hline ROK & K & L & Q \\
\hline \hline 1996 & 782568 & 6702,704 & 4922082 \\
\hline 1997 & 1085864 & 6724,792 & 5849325 \\
\hline 1998 & 1191815 & 6499,896 & 5406106 \\
\hline 1999 & 1240980 & 6019,984 & 6906758 \\
\hline 2000 & 1339077 & 5827,216 & 7917348 \\
\hline 2001 & 1352772 & 5869,384 & 9464295 \\
\hline 2002 & 1688971 & 6285,04 & 12157033 \\
\hline 2003 & 2016809 & 6291,064 & 13662827 \\
\hline 2004 & 2346223 & 6303,112 & 18106286 \\
\hline 2005 & 2833587 & 6684,632 & 20786110 \\
\hline
\end{tabular}


Hodnoty K, L a Q zlogaritmujeme (v programe Excel pomocí př́kazu LN).

\begin{tabular}{||c|c|r|c||}
\hline \hline ROK & $\mathbf{k}$ & $\mathbf{l}$ & $\mathbf{q}$ \\
\hline \hline 1996 & 13,5703361 & 8,810266306 & 15,40924217 \\
\hline 1997 & 13,89788654 & 8,813556275 & 15,58183683 \\
\hline 1998 & 13,99098791 & 8,779541456 & 15,50303961 \\
\hline 1999 & 14,03141195 & 8,70283988 & 15,74801091 \\
\hline 2000 & 14,10749113 & 8,670294635 & 15,88456686 \\
\hline 2001 & 14,11766638 & 8,677504967 & 16,06303685 \\
\hline 2002 & 14,33963003 & 8,745927485 & 16,31341841 \\
\hline 2003 & 14,51702712 & 8,746885493 & 16,43018935 \\
\hline 2004 & 14,66831736 & 8,748798759 & 16,71176973 \\
\hline 2005 & 14,85705396 & 8,807566439 & 16,84979553 \\
\hline
\end{tabular}

Dále postupujeme podle kroku 1,2,3.

\begin{tabular}{||l|c||}
\hline & Koeficienty \\
\hline \hline Hranice & 0,294753689 \\
\hline Soubor X 1 & 1,275149815 \\
\hline Soubor X 2 & $-0,270260171$ \\
\hline
\end{tabular}

Konstantu $a_{0}$ získáme

$$
a_{0}=e^{0,294753689}
$$

a to je

$$
a_{0}=1,342795572 .
$$

Produkční funkce spol. Metrostav je tedy

$$
Q=1,342795572 \cdot K^{1,275149815} \cdot L^{-0,270260171}
$$

Grafické znázornění této funkce je na obrázku č. 5. Vidíme zde produkční kopec produkční funkce spol. Metrostav, která nemá klasický průběh. Je ovlivněna především zápornou hodnotou konstanty $a_{2}$. Přes svůj netradiční průběh má funkce rostoucí výnosy $\mathrm{z}$ rozsahu $\left(a_{1}+a_{2}>1\right)$. 
Obr. č. 1: Produkční funkce spol. Metrostav a.s.
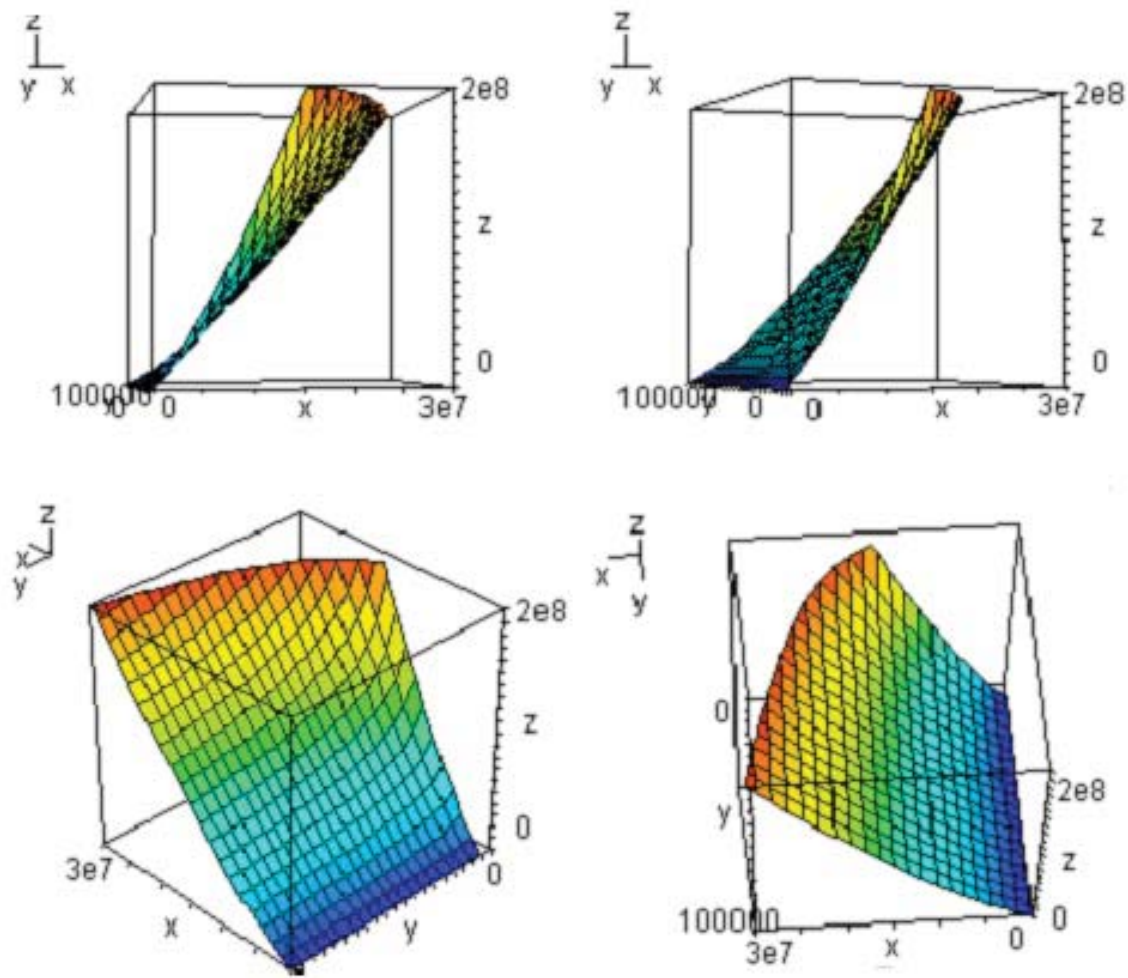

\section{Produkční funkce Skanska a.s.}

V dále budu zjiš ovat produkční funkci pro společnost Skanska a.s. z dat z období 2001-2005.

\begin{tabular}{||c|c|c|c||}
\hline \hline ROK & K & L & Q \\
\hline \hline 2001 & 3709000 & 13078,104 & 23938000 \\
\hline 2002 & 4592000 & 12921,480 & 28511000 \\
\hline 2003 & 5702000 & 13405,408 & 29462000 \\
\hline 2004 & 6978000 & 14142,344 & 33903000 \\
\hline 2005 & 6776000 & 14555,992 & 36455000 \\
\hline
\end{tabular}

\begin{tabular}{|c|c|c|c|}
\hline ROK & $\mathbf{k}$ & $\mathbf{l}$ & $\mathbf{q}$ \\
\hline 2001 & 15,12627286 & 9,47869466 & 16,99097771 \\
\hline 2002 & 15,33982622 & 9,46664632 & 17,16580054 \\
\hline 2003 & 15,55632755 & 9,50341349 & 17,19861186 \\
\hline 2004 & 15,75827290 & 9,55692870 & 17,33901406 \\
\hline 2005 & 15,72889752 & 9,58575801 & 17,41158918 \\
\hline
\end{tabular}

Produkční funkce spol. Skanska a.s. je

$$
Q=1,110493 \cdot K^{0,460205} \cdot L^{0,740814} .
$$


Obr. č. 2: Produkční funkce spol. Skanska a.s.
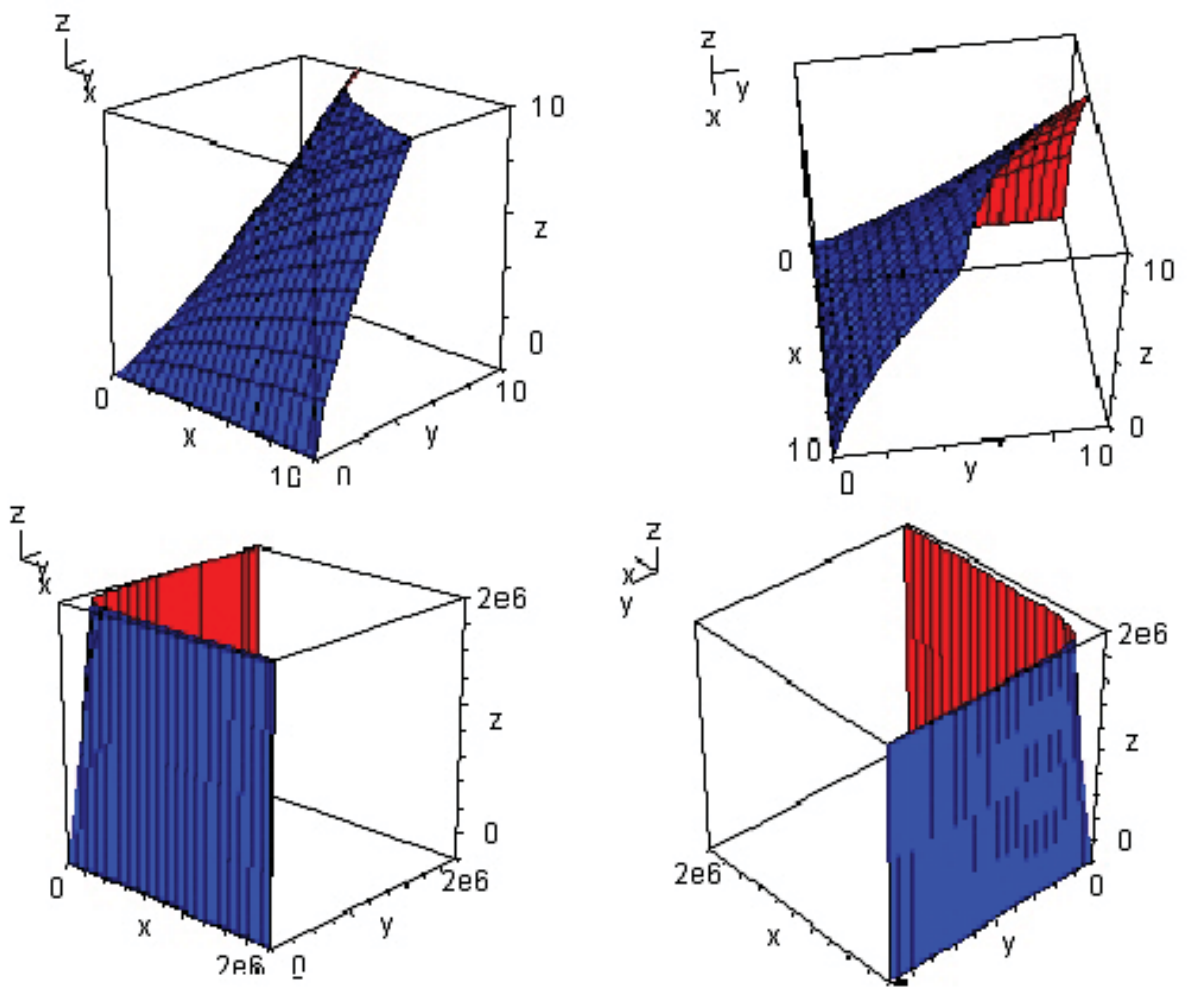

Obr. č. 3: Grafické porovnání produkčních funkcí obou stavebních společností
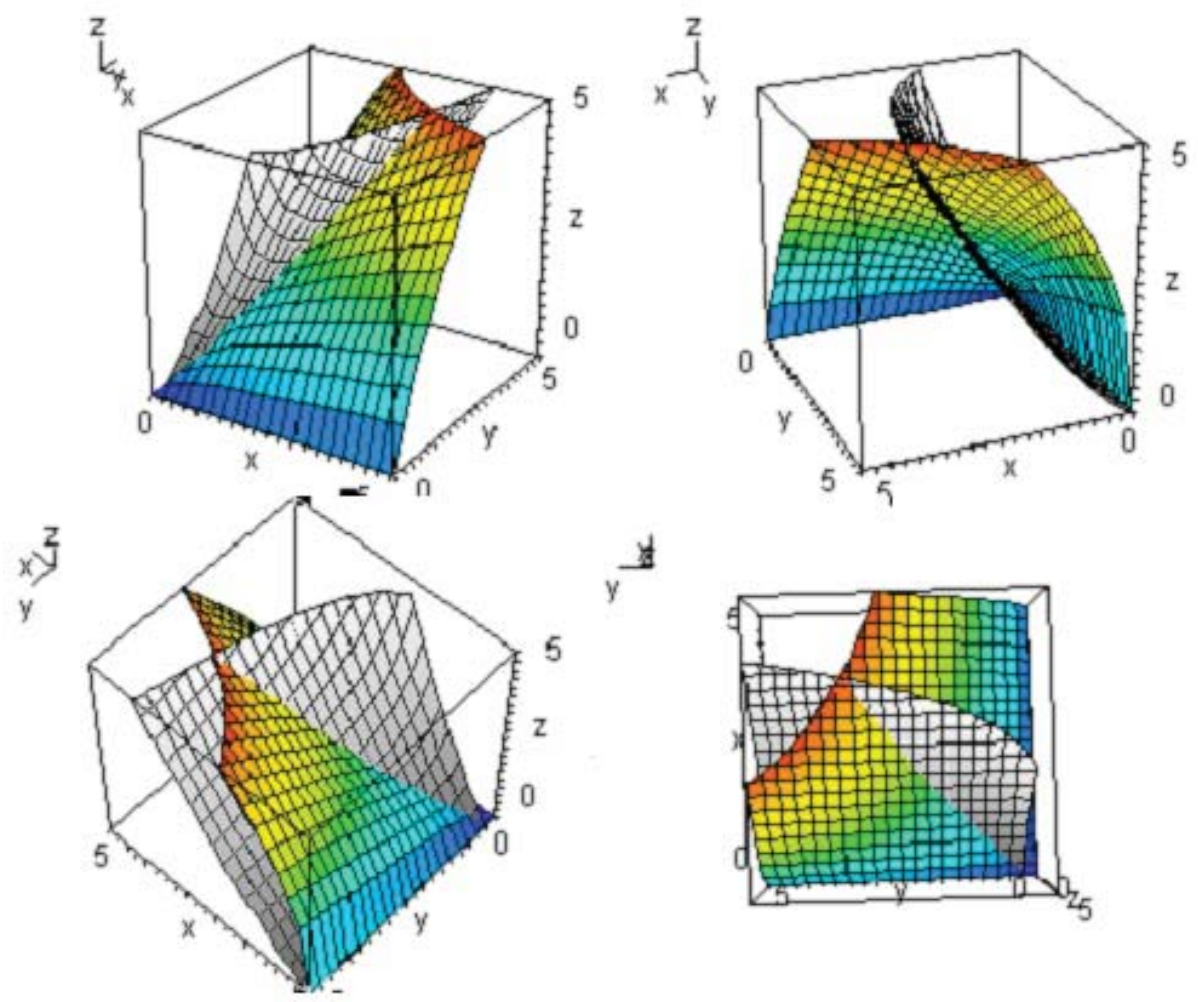

Obrázek č. 3 znázorňuje produkční kopec průběh produkční funkce spol. Skanska a.s. Oproti produkční funkci spol. Metrostav má obě konstanty $a_{1}, a_{2}$ kladné. Produkční funkce má rostoucí výnosy z rozsahu $\left(a_{1}+a_{2}>1\right)$. 
Abychom mohli obě produkční funkce vzájemně lépe porovnat, zobrazíme jejich produkční funkce do jednoho grafu (viz Obrázek č. 7). Průsečík produkčních kopců je množina kombinací vstupů K a L (kapitál a práce), kdy společnosti dosahují stejné velikosti výstupu Q (produkce). Oba produkční kopce se od sebe velice liší. Jejich tvar a zakřivení je způsobeno především hodnotami konstant $a_{1}, a_{2}$.

\section{Závěr}

Produkční funkce spol. Metrostav a.s. má netradiční průběh, který způsobují její konstanty $a_{1}, a_{2}$. Hodnoty konstant klasických produkčních funkcí se totiž pohybují v intervalech $a_{1} \in(0,1), a_{2} \in(0,1)$. Na Cobb-Douglasově rovnici produkční funkce

$$
Q=f(K, L)=a_{0} K^{a_{1}} L^{a_{2}}
$$

vidíme, že produkce (velikost tržeb) se v našem případě snižuje se zvyšujícími se vstupy práce L je-li konstanta $a_{2}$ záporná. Díky zvyšujícím se vstupům kapitálu K se produkce přesto zvyšuje Konkrétně v našem př́ípade je to

$$
Q=\frac{1,342795572 \cdot K^{1,275149815}}{L^{0,270260171}} .
$$

Produkční funkce spol. Skanska a.s. má klasičtější průběh díky kladným hodnotám obou konstant $a_{1}, a_{2}$. Které sice nejsou v intervalu (0,1). Na obrázku č. 7 máme možnost vidět jak hodnoty konstanty $a_{1}$ ovlivňují produkční funkci. Na obrázku č. 8 je znázorněno jak ovlivňuje konstanta $a_{2}$ produkční funkci.

\section{Obr. č. 4: Vliv velikosti parametru $a_{1}$}

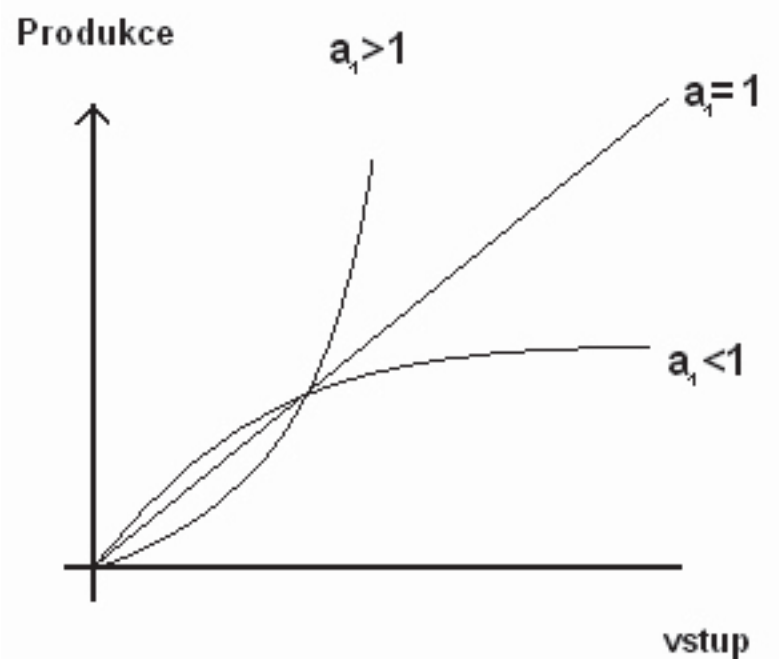




\section{Obr. č. 5: Produkční funkce pro záporné hodnoty parametru a}

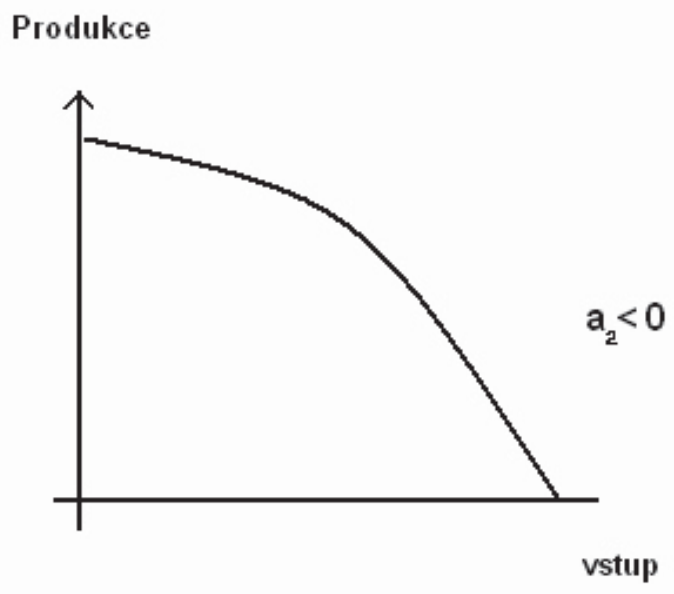

V závěru této práce bych rád vyzdvihl Společnost Metrostav a.s. a to z prostého důvodu. Vybíral jsem z mnoha velkých a známých společností se stejným zaměřením, ale pouze tato společnost uvádí výroční zprávy za období 10 let. Ostatní firmy poskytují výroční zprávy z období 3 let, které jsou velice strohé (např. spol. Skanska a.s.), nebo je neposkytují vůbec.

\section{Literatura}

[1] BARTOŠOVÁ, J. 2004. Mikro a makroekonomické úlohy řešené pomocí programu Derive5. Oeconomica, VŠE Praha, 2004, ISBN 80-245-0758-7

[2] BARTOŠOVÁ, J. 2007. Modelování v ekonomii podpůrný učební text k on-line kurzu 6MI420. Oeconomica, VŠE Praha, 2007, ISBN 978-80-245-1162-7

[3] BARTOŠOVÁ, J.,Kincl, T. Derive5, staženo z: <http://mi.fm.vse.cz/profil/zakladni_informace/halvni_zamery_strategie>

[4] Hlavní záměry společnosti Metrostav a.s., staženo z: <http://www.metrostav.cz/cz/profil/zakladni_informace/hlavni_zamery_strategie>

[5] STUCHLÝ, J. 2000. Ekonometrie učební text.VŠE Praha, Fakulta managementu, Jindřichův Hradec, 2000

[6] Tisková zpráva Metrostav a.s. 2004

[7] VARIAN, H. R. 1995. Mikroekonomie moderní př́stup. Praha, Victoria Publishing, 1995, ISBN 80-85865-25-4

[8] Výroční zpráva Metrostav a.s. 1996

[9] Výroční zpráva Metrostav a.s. 1997

[10] Výroční zpráva Metrostav a.s. 1998

[11] Výroční zpráva Metrostav a.s. 1999

[12] Výroční zpráva Metrostav a.s. 2000

[13] Výroční zpráva Metrostav a.s. 2001

[14] Výroční zpráva Metrostav a.s. 2002

[15] Výroční zpráva Metrostav a.s. 2003 
[16] Výroční zpráva Metrostav a.s. 2004

[17] Výroční zpráva Metrostav a.s. 2005

[18] Výroční zpráva Skanska a.s. 2001

[19] Výroční zpráva Skanska a.s. 2002

[20] Výroční zpráva Skanska a.s. 2003

[21] Výroční zpráva Skanska a.s. 2004

[22] Výroční zpráva Skanska a.s. 2005 